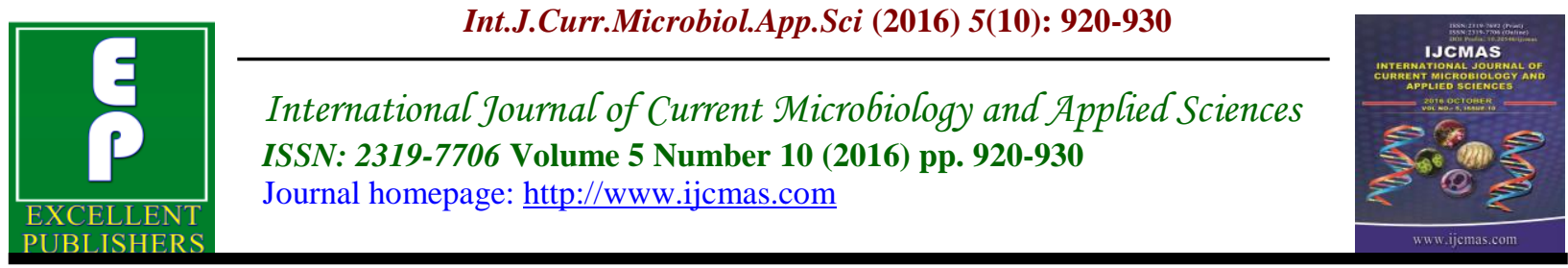

Original Research Article

http://dx.doi.org/10.20546/ijcmas.2016.510.099

\title{
Phycoremediation of Heavy Metals by Chlorella pyrenoidosa and Spirogyra communis
}

\author{
Meenakshi Sati*, Megha Verma and J.P.N. Rai \\ Department of Environmental Sciences, College of Basic Sciences and Humanities, G.B. Pant \\ University of Agriculture and Technology, Pantnagar, Uttarakhand, India \\ *Corresponding author
}

Keywords

Phycoremediation,

Heavy Metals,

Chlorella

pyrenoidosa,

Spirogyra

communis.

Article Info

Accepted:

26 September 2016

Available Online:

10 October 2016

\section{A B S T R A C T}

In the present study, the phycoremediation capacities of live green algae, Chlorella pyrenoidosa and Spirogyra communis were evaluated for toxic heavy metals, $\mathrm{Pb}(\mathrm{II}), \mathrm{Cu}(\mathrm{II})$ and $\mathrm{Cr}(\mathrm{IV})$ from electroplating industrial effluent and synthetic solution. Both the algae proved efficient biological vectors for heavy metal uptake. Phycoremediation studies conducted on industrial effluent revealed that $100 \% \mathrm{~Pb}$ was removed from $20 \%$ effluent concentration in 20 days by both algae. Experimental results revealed that Chlorella pyrenoidosa and Spirogyra communis had maximum accumulation of $\mathrm{Pb}$ (II) followed by $\mathrm{Cu}$ (II) and $\mathrm{Cr}$ (IV) after 20 days of exposure. The growth performance of the two algae measured in terms of $\mathrm{Chl}$ a content was maximally reduced by $\mathrm{Cr}\left(>30 \mathrm{mg} \mathrm{L}^{-1}\right)$ while it was enhanced by low levels of $\mathrm{Pb}$ and $\mathrm{Cu}\left(<50 \mathrm{mg} \mathrm{L}^{-1}\right)$.

\section{Introduction}

Environmental contamination by heavy metals is a serious problem due to their incremental accumulation in the food chain. Unlike most organic wastes and the microbial load in aquatic bodies, metal contaminants are not biodegradable, tending to accumulate in living organisms, thus becoming a permanent burden on ecosystems (Bayo, 2012). Most heavy metals are transition elements with incompletely filled d-orbitals. These $d$ orbitals provide heavy metal cations with the ability to form complex compounds. Trace amounts $\left(\mu \mathrm{g} \mathrm{L}^{-1}\right)$ of some metal ions such as copper, zinc, cobalt, iron, nickel are required by living organisms as cofactors for the enzymatic activities. However, heavy metal ion concentrations at ppm $\left(\mathrm{mg} \mathrm{L}^{-1}\right)$ level are known to be toxic to the organisms because of irreversible inhibition of many enzymes by the heavy metal ions. The process of accumulation and adsorption of metals by algae involves adsorption onto the cell surface (wall, membrane or external polysaccharides) and binding to cytoplasmic ligands, phytochelatins and metallothioneins, and other intracellular molecules. The algal cell wall has many 
functional groups, such as hydroxyl $(\mathrm{OH})$, phosphoryl $\left(\mathrm{PO}_{3} \mathrm{O}_{2}\right)$, amino $\left(\mathrm{NH}_{2}\right)$, carboxyl $(\mathrm{COOH})$, sulphydryl $(\mathrm{SH})$, etc., which confer negative charge to the cell surface (Gonzalez et al., 2012; Bulgariu and Bulgariu, 2014). Since metal ions in water are generally in the cationic form, they are adsorbed onto the cell surface (Crist et al., 1992; Xia and Liyuan, 2004; Romera et al., 2007; Singh et al., 2012). Algal cell walls are porous and allow the free passage of molecules and ions in aqueous solutions. The constituents of the algal cell wall provide an array of ligands with different functional groups capable of binding various heavy metals. These cells can be used live or dead (Zou et al., 2014). They are generally rugged organisms with fast growth in simple medium, and the algal biomass produced can easily be processed into useful biosorbents (Tuzen and Sary, 2010).

The present study therefore aimed to compare the performance of Chlorella pyrenoidosa and Spirogyra communis in sequestering $\mathrm{Pb}$ (II), $\mathrm{Cu}$ (II) and $\mathrm{Cr}(\mathrm{IV})$ ions from industrial and aqueous solutions. The growth performance of the two algal species in terms of their Chl content after heavy metals accumulation was also examined. Both the algae were distinct from each other in their morphology, one is unicellular while other is multicellular. In literature no such study has been undertaken so far where a comparison is made between two morphologically distinct algae for bioremediation of heavy metals.

\section{Materials and Methods}

\section{Preparation of algal cultures}

Chlorella pyrenoidosa and Spirogyra communis were used as biosorbents for the bioremediation of heavy metals lead, chromium and copper from industrial effluent as well as from aqueous solutions. Spirogyra communis was collected from the ponds located in Fisheries college, G.B. Pant University, Pantnagar while Chlorella pyrenoidosa (NCIM No.-2738) was obtained as pure culture from CSIR-National Chemical Laboratory, Pune-411008. Both the cultures were further maintained in Fog's medium. Slant cultures were prepared from the pure culture for further use. One loopful of algal biomass from best growth obtained above was inoculated in a sterile $15 \mathrm{ml}$ test tube with enriched medium (Fog's Medium). Total 20 numbers of $15 \mathrm{ml}$ test tubes were inoculated with isolated algae, maintained at $24^{\circ} \mathrm{C} \pm 1^{\circ} \mathrm{C}$ and illuminated at 4000 lux light intensity with a light/dark cycle of 16/8-h for 10 days. After 10 days, inoculated algae from the test tubes were inoculated into $250 \mathrm{ml}$ Erlenmeyer flasks containing Fog's Medium for another 7 days. After seven days the medium inside the flask appear green, these were examined under microscope. At every 12 days new medium was prepared and the algal cells were inoculated to it to continue the algal cell generation. To avoid bacterial and fungal contamination appropriate amount of antifungal and antibacterial were added to the medium.

\section{Preparation of heavy metal stock solutions}

Stock solutions of $\mathrm{Pb}$ (II), $\mathrm{Cu}$ (II) and $\mathrm{Cr}$ (IV) were prepared by dissolving their salts viz. lead nitrate $\mathrm{Pb}\left(\mathrm{NO}_{3}\right)_{2}$, copper sulphate $\mathrm{CuSO}_{4}$ and potassium dichromate $\mathrm{K}_{2} \mathrm{Cr}_{2} \mathrm{O}_{7}$ in distilled water. From this stock solution different concentration of heavy metals were prepared $\left(30,50,100,150\right.$ and $\left.200 \mathrm{mg} \mathrm{L}^{-1}\right)$.

\section{Analysis of Electroplating effluent}

Electroplating effluent was analysed for various chemical and physical parameters 
such as pH, BOD, COD, DO, TDS and Heavy metal estimation by standard prescribed methods in APHA (1995).

\section{Analysis of algae}

\section{Measurement of Chlorophyll}

Chlorophyll a content in $S$. communis and $C$. pyrenoidosa was determined according to Vonshak (1997) where, 3g of fresh sample was ground in a mortar and pestle. Tissue was formed to a fine pulp with addition of $20 \mathrm{ml}$ of $80 \%$ acetone. Centrifuge $(5000 \mathrm{rpm}$ for $5 \mathrm{~min}$.) and the supernatant was transferred to a conical flask. This procedure was repeated until the residue was colourless. The mortar and pestle was washed thoroughly with $80 \%$ acetone and the clear washings was collected in the volumetric flask. The volume was made to $50 \mathrm{ml}$ with $80 \%$ acetone. The absorbance of the solution was read at 645 and $663 \mathrm{~nm}$ against the solvent (80\% acetone) blank using spectrophotometer, and then amount of Chl a ( $\left.\mathrm{mg} \mathrm{g}^{-1}\right)$ concentrations in the algal tissues were calculated according to the following equation:

Chl a $=12.7(\mathrm{~A} 663)-2.69(\mathrm{~A} 645) \times \mathrm{V} / 1000$ $\times \mathrm{W}$

Where,

$\mathrm{A}=$ absorbance at specific wavelength

$\mathrm{V}=$ final volume of chlorophyll extract in $80 \%$ acetone $(\mathrm{ml})$

$\mathrm{W}=$ fresh weight of the tissue extracted $(\mathrm{g})$

\section{Phycoremediation Experiments}

Algal metal bioremoval from industrial effluent was assayed by exposing $S$. communis (3 g FW) and C. pyrenoidosa (10 $\mathrm{ml})$ to $100 \mathrm{ml}$ waste water effluent (containing growth medium for algal biomass) in $250 \mathrm{~mL}$ conical flask separately. The experiments were performed in triplicates. The flasks were incubated for 10 and 20 days along with control for each day (without algae) at $20^{\circ} \mathrm{C}$, under cool fluorescent lamps at maximum intensity of 3200 lux and periodicity of 12/12 hour Light/Dark. After 10 and 20 days the flasks were removed and analysed for heavy metal content using AAS. For aqueous solution the experiments were conducted with $\mathrm{Pb}, \mathrm{Cu}$ and $\mathrm{Cr}$ at concentrations 10, 30, 50 and 70 $\mathrm{mg} \mathrm{L}^{-1}$ for each metal for 24 days, after which the growth performance of algae was measured in terms of Chl. content $(\mathrm{mg} / \mathrm{g})$. The samples were digested using Nitric acid-perchloric acid method and were analysed for heavy metal concentration using AAS.

\section{Results and Discussion}

\section{Characterization of biosorbents}

Qualitative studies regarding binding sites of heavy metals on the surface of biosorbents under investigation ( $S$. communis and $C$. pyrenoidosa) were carried out by Fourier Transform Infra-Red (FTIR) Spectroscopy (Fig. 1 and 2). FTIR spectroscopy gives valuable information about the nature of the bonds present and allows identification of functional sites such as carboxyl, sulfonate, hydroxyl, and amino groups on the cell surface.

These groups have been proposed to be responsible for the biosorption of metals by algae. The region between 3200-3500 cm-1 exhibits the stretching vibration of $\mathrm{O}-\mathrm{H}$ and $\mathrm{N}-\mathrm{H}$ which also confirms the presence of hydroxyl and amine functional groups in both algal structure. The region between $3000-2800 \mathrm{~cm}^{-1}$ shows the $\mathrm{C}-\mathrm{H}$ stretching 
vibrations of $\mathrm{sp} 3$ hybridized $\mathrm{C}$ in $\mathrm{CH}_{3}$ and $\mathrm{CH}_{2}$ functional groups. The peaks at 1652 $\mathrm{cm}^{-1}$ (for S. communis), and $1649 \mathrm{~cm}^{-1}$ (for C. pyrenoidosa) reveal the presence of carbonyl group. The presence of amide in the structure of each alga is confirmed by the peak at $1545 \mathrm{~cm}^{-1}$ (for $S$. communis), and $1543 \mathrm{~cm}^{-1}$ (for $C$. pyrenoidosa). The absorption peaks around $1240 \mathrm{~cm}-1$ and $1150 \mathrm{~cm}^{-1}$ indicate the phosphate esters in $S$. communis and $C$. pyrenoidosa. The phosphate esters are the source of phosholipids. The absorption peaks at the respective frequencies of $1026 \mathrm{~cm}^{-1}$ confirm the presence of sulfoxides in $S$. communis which are absent in $C$. pyrenoidosa. The observed frequencies in FTIR spectra of the algae used indicate the presence of amine $\left(\mathrm{R}-\mathrm{NH}_{2}\right), \quad$ amide $\quad\left(\mathrm{R}_{1}(\mathrm{CO}) \mathrm{NR}_{2} \mathrm{R}_{3}\right)$ (aminoacids, proteins, glycoproteins, etc.), carboxylic acids (fatty acids, lipopolysaccharides, etc.), sulfoxides (in case of $S$. communis) and phosphates

\section{Change in physicochemical parameters of electroplating effluent after treatment with $C$. pyrenoidosa and $S$. communis}

The industrial effluents contain various toxic contaminants including heavy metals as cadmium, nickel, mercury, arsenic, copper etc. producing a significant toxic impact on aquatic environment (Singh et al., 2006; Siddiqui and Sharma, 2009; Oyeku et al., 2010 and Pandey et al., 2010). Data represented in Table 1 and Fig. 3 clearly indicates the changes in physicochemical parameters and heavy metal concentration of electroplating effluent before and after treatment with algae $S$. communis and $C$. pyrenoidosa. After 20 days there was $100 \%$ removal of $\mathrm{Pb}$ by both algal biomass. $88.32 \%$ and $84.75 \%$ reduction in $\mathrm{Cu}$ and $\mathrm{Cr}$ content was observed by $C$. pyrenoidosa while a reduction of $94 \%$ and $60 \%$ was observed for $\mathrm{Cu}$ and $\mathrm{Cr}$ by $S$. communis after 20 days of treatment (Fig. 4). Moreover, a significant change was observed in physicochemical parameters of electroplating effluent after 20 days of treatment with both algae under investigation. Study suggests that $C$. pyrenoidosa and $S$. communis shows promising approach towards the purification process of waste water at various parameters. Along with bringing the properties such as TDS, $\mathrm{pH}, \mathrm{BOD}, \mathrm{COD}$ etc. towards the desirable limit, both the algae has been found quite effective for the removal of heavy metals also. Among heavy metals, although a significant reduction was observed in all the three metals but the algae has been found to be especially effective in the reduction of $\mathrm{Pb}$, followed by $\mathrm{Cu}$ and $\mathrm{Cr}$.

\section{Effect of varied metal treatments on algae growth with respect to $\mathrm{Chl}$ "a" content}

The data represented in Fig. 5 shows chlorophyll "a" content of S. communis and $C$. pyrenoidosa and was found to be affected by different metal treatments. It can be seen from figures that the two algae tolerated the toxicity of $\mathrm{Pb}$ even at higher concentrations $(10-50 \mathrm{mg} / \mathrm{l})$ moreover the lower concentration of $\mathrm{Pb}(10 \mathrm{mg} / \mathrm{l})$ induced a pronounced stimulation of chlorophyll "a" which was observed in both algae under investigation. On the other hand, $\mathrm{Cr}$ showed a strong inhibition of chlorophyll a biosynthesis even at the lower concentrations $(10 \mathrm{mg} / \mathrm{l})$ in both the algae and a complete destruction of the algal cell at concentration above $10 \mathrm{mg} / \mathrm{l}$ (Fig. 1 and 2 ). This means that the efficiency of the photosynthetic apparatus seemed to be less affected by $\mathrm{Pb}$ and severely altered by $\mathrm{Cr}$. $\mathrm{Cu}$ toxicity was mostly intermediate (between that of $\mathrm{Cr}$ and $\mathrm{Pb}$ ), it exhibited stimulatory effect to the algal growth (chlorophyll a) at lower concentrations (10$30 \mathrm{mg} / \mathrm{ml}$ ) in case of $C$. pyrenoidosa while 
in $S$. communis the enhancement effect was only restricted to concentration of $10 \mathrm{mg} / \mathrm{l}$. The obtained results in this investigation concerning the tolerance of S. communis and $C$. pyrenoidosa to the tested heavy metal ions $(\mathrm{Pb}, \mathrm{Cu}$ and $\mathrm{Cr})$ were in agreement with the results reported by Foster, 1982 and Stokes, 1983 concerning the tolerance and resistance of green algal species to heavy metal ions $(\mathrm{Cu}, \mathrm{Cd}, \mathrm{Pb}$ and $\mathrm{Zn})$. Increased chlorophyll ratios due to environmental stress have been reported in spinach leaves
(Delfine et al., 1999; Monni et al., 2001). The chlorophylls level in Olisthodiscus luteus decreased to $86.7 \%$ after $180 \mathrm{hr}$ exposure to $0.5 \mathrm{mg} / \mathrm{l} \mathrm{Cr}^{2+}$. In addition, high $\mathrm{Cr}^{2+}$ concentrations reduced cell sizes and caused a decrease in growth rate (Fernandez-Leborans and Novillo, 1996). Nassiri et al., (1997) found no growth inhibition at $\mathrm{Cr}^{2+}$ concentrations $<1 \mathrm{mg} / \mathrm{l}$, but Tetraselmis suecica had 10, 30 and 50\% growth inhibition, after 4 days in solutions contained 2, 5 and $10 \mathrm{mg} / \mathrm{Cr}^{2+}$ respectively.

Table.1 Physicochemical parameters of electroplating effluent before and after treatment (20 days) with algae

\begin{tabular}{|l|l|l|l|}
\hline \multirow{2}{*}{ Parameters } & \multicolumn{3}{|c|}{ Values } \\
\cline { 2 - 4 } & Raw effluent & $\begin{array}{l}\text { Treated with } \\
\text { C. pyrenoidosa }\end{array}$ & $\begin{array}{l}\text { Treated } \\
\text { S. communis }\end{array} \quad$ with \\
\hline Colour & Dark brown & Lightened & Lightened \\
\hline Odour & Acidic smell & Neutral smell & Neutral smell \\
\hline $\mathrm{pH}$ & 5.83 & 7.34 & 6.98 \\
\hline $\mathrm{TDS}(\mathrm{mg} / \mathrm{L})$ & 60 & 44 & 42 \\
\hline $\mathrm{DO}(\mathrm{mg} / \mathrm{L})$ & 7.73 & 6.32 & 6.12 \\
\hline $\mathrm{BOD}(\mathrm{mg} / \mathrm{L})$ & 148 & 54 & 48 \\
\hline $\mathrm{COD}(\mathrm{mg} / \mathrm{L})$ & 167 & 74 & 77 \\
\hline $\mathrm{Zn}(\mathrm{mg} / \mathrm{L})$ & 39 & 12 & 10 \\
\hline $\mathrm{Cd}(\mathrm{mg} / \mathrm{L})$ & 0.015 & 0.004 & 0.007 \\
\hline
\end{tabular}

Fig.1 FTIR spectra of Chlorella pyrenoidosa (a) Native (b) Pb loaded
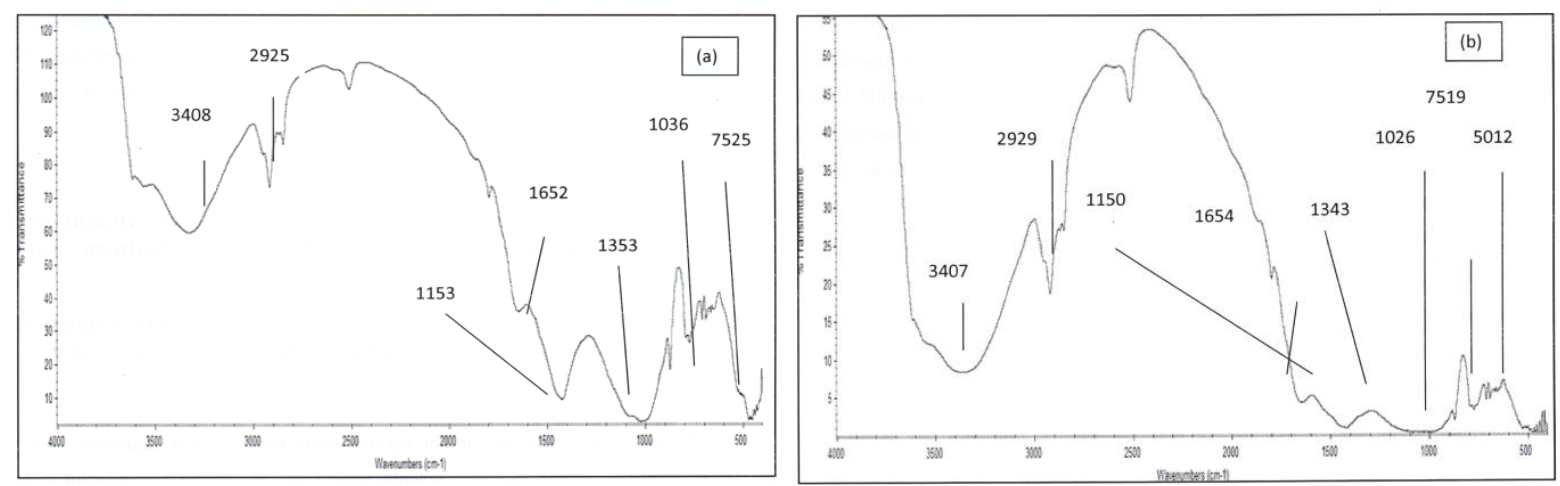
Fig.2 FTIR spectra of $S$. communis (a) Native (b) Pb loaded
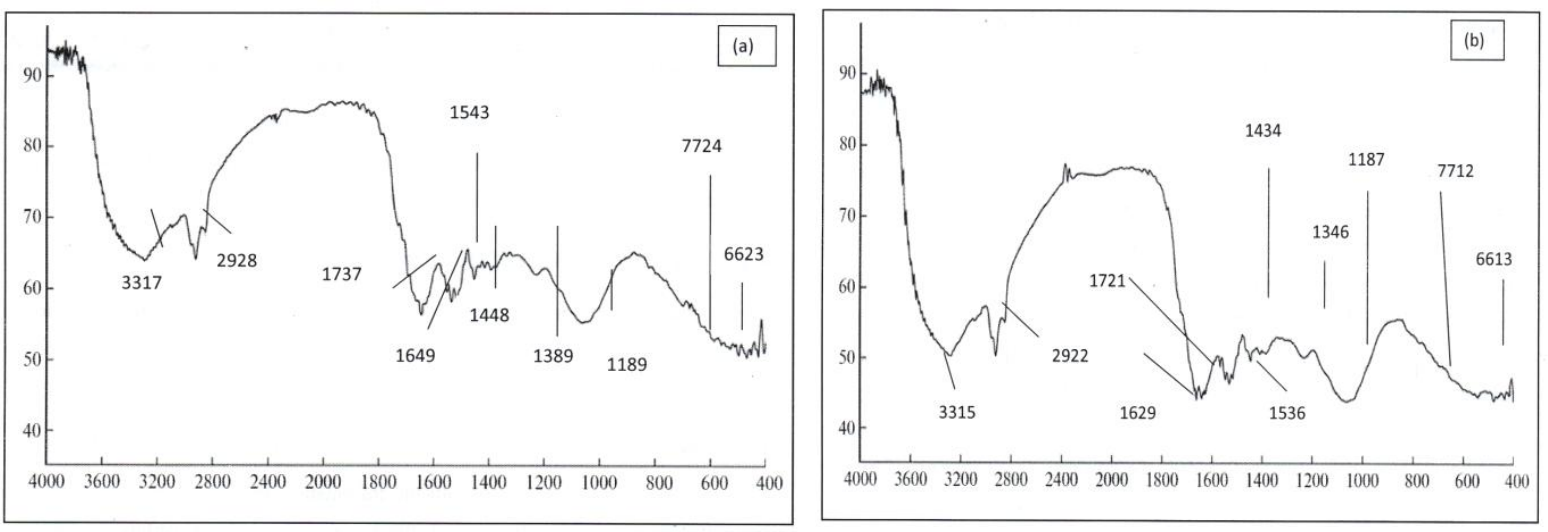

Fig.3 Change in concentration of heavy metals $[(\mathrm{a}) \mathrm{Pb},(\mathrm{b}) \mathrm{Cu},(\mathrm{c}) \mathrm{Cr}]$ in electroplating industrial effluent after treatment with $C$. pyrenoidosa and $S$. communis
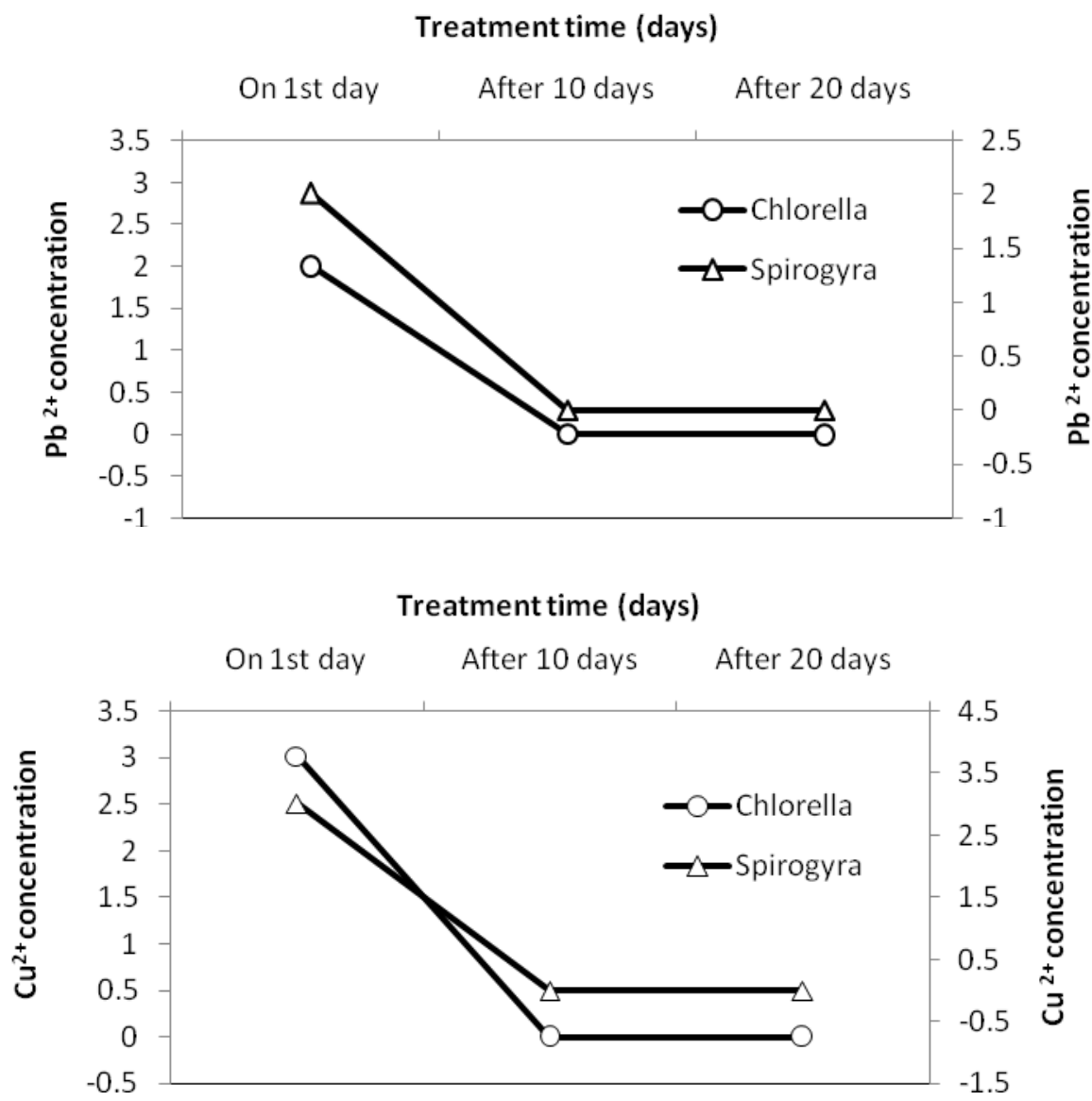


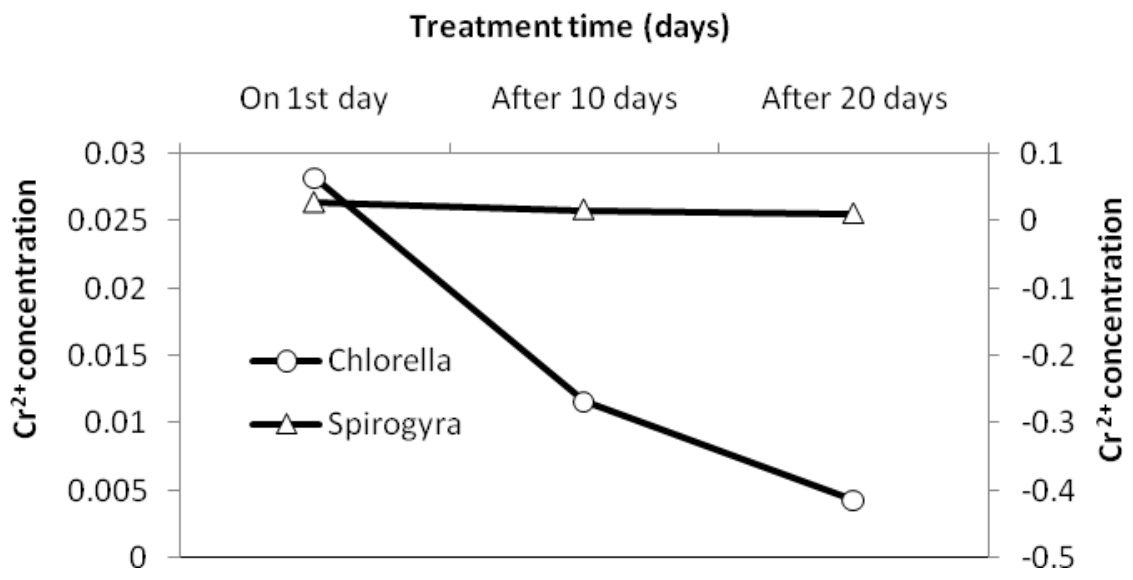

Fig.4 Percent reduction in heavy metal concentration $[(\mathrm{a}) \mathrm{Pb}$, (b) $\mathrm{Cu}$, (c) $\mathrm{Cr}]$ of electroplating industrial effluent after treatment with $C$. pyrenoidosa and $S$. communis
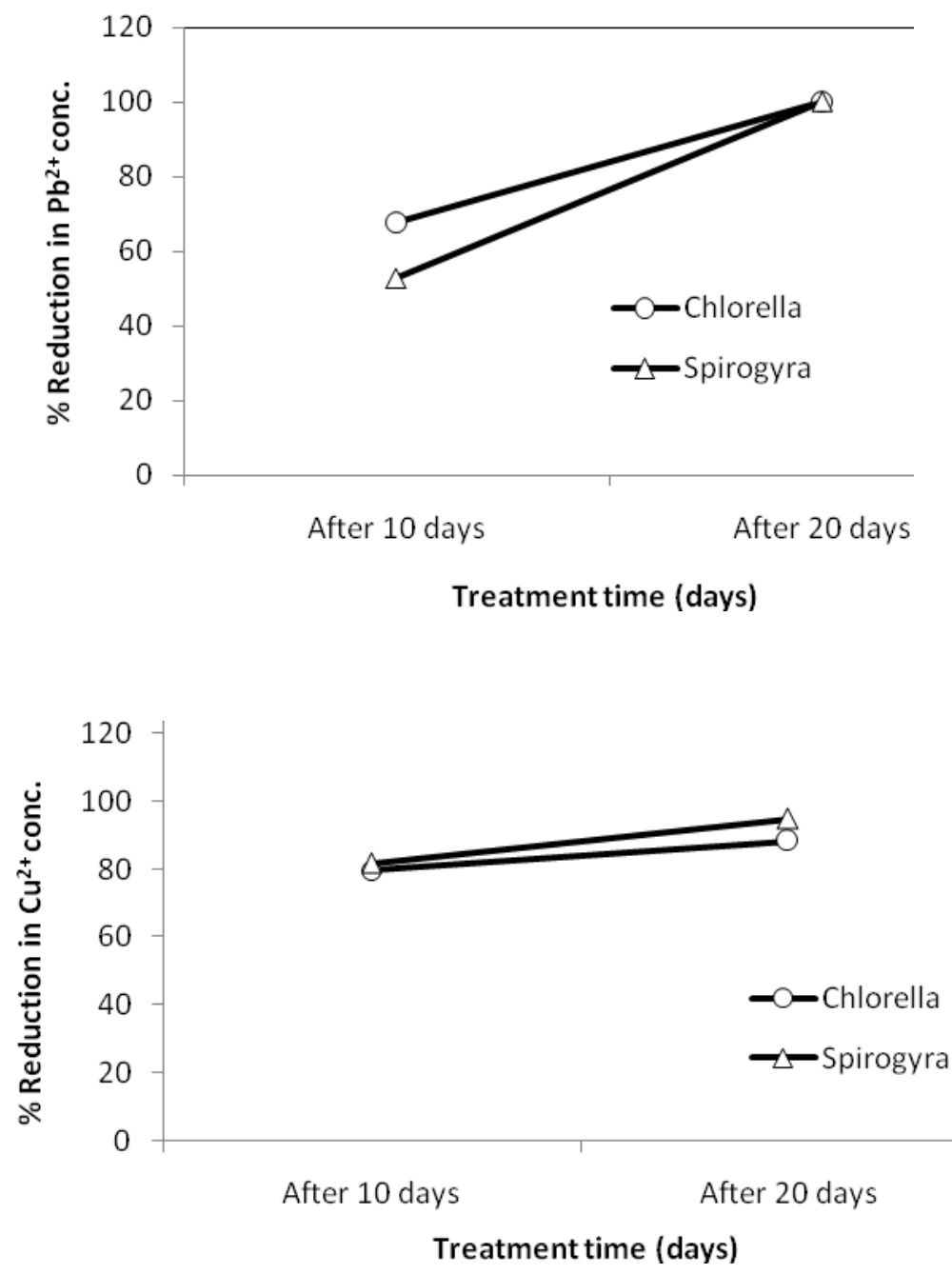


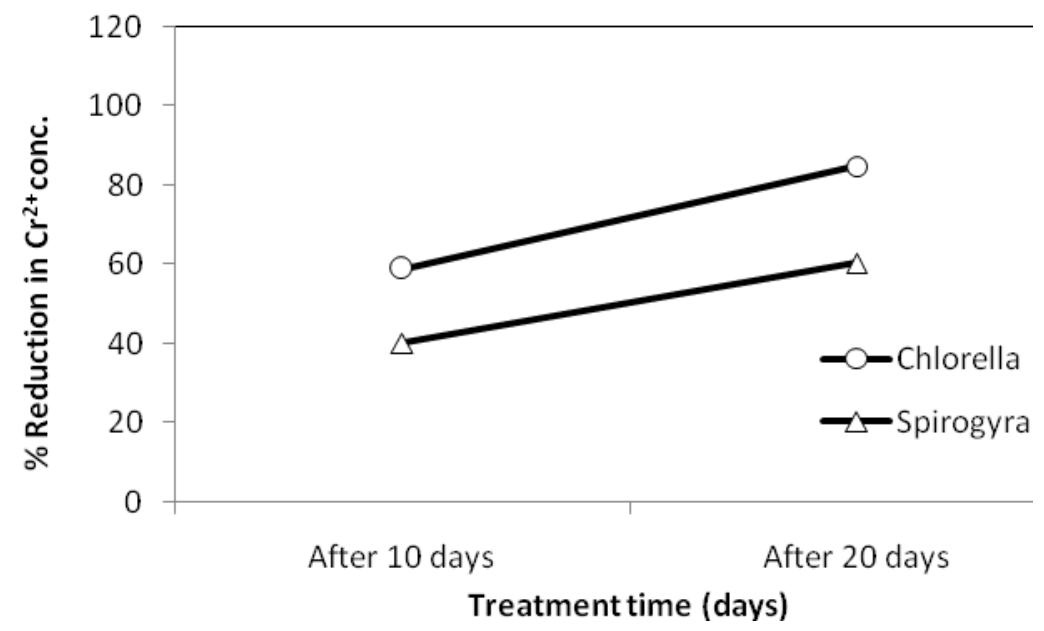

Fig.5 Effect of different heavy metals concentration on Chlorophyll a content (mg g-1) of $S$. communis (a) and C. pyrenoidosa (b) after 24 days of exposure
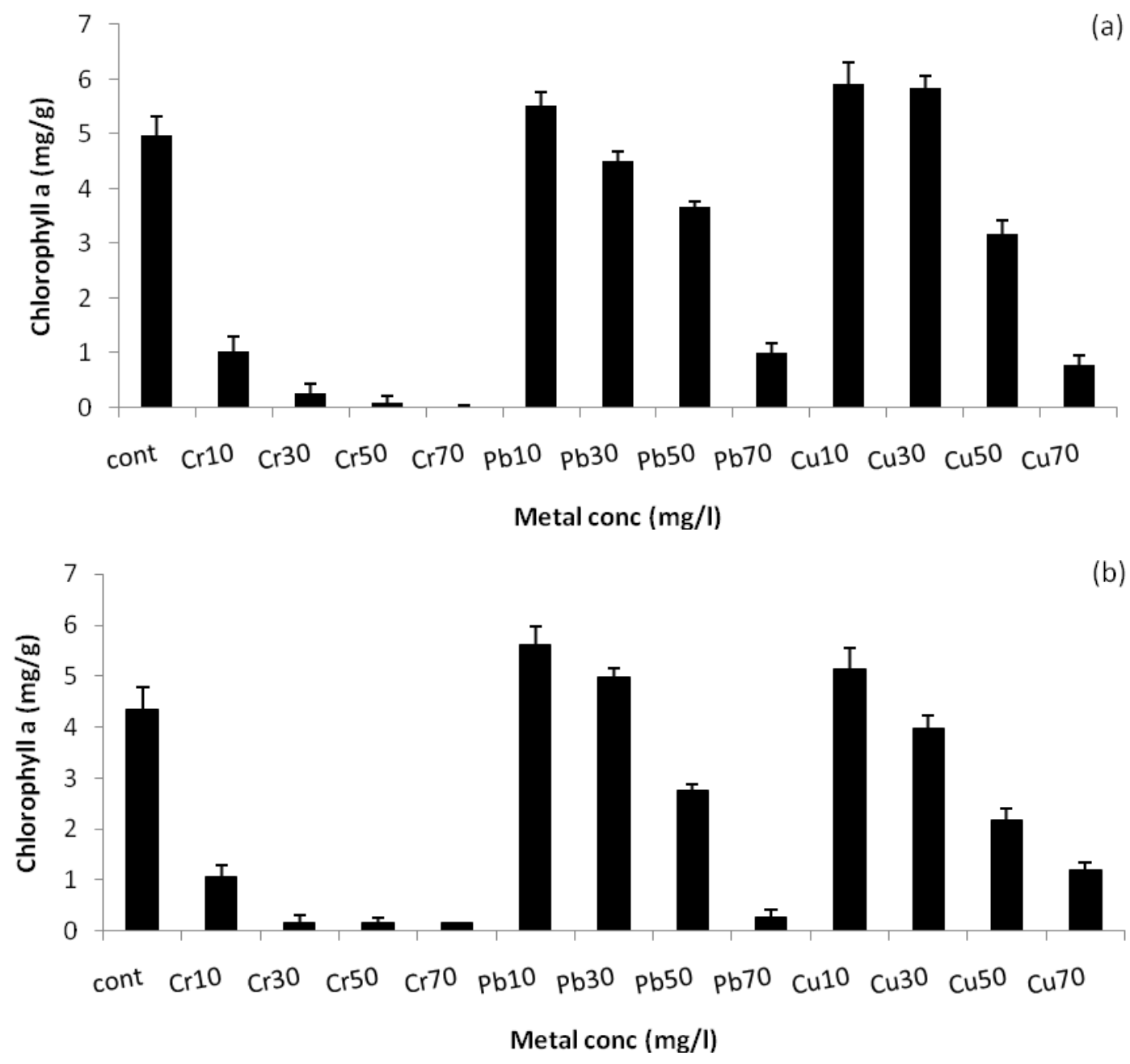
Decreased chlorophyll content associated with heavy metal stress may be the result of inhibition of the enzymes responsible for chlorophyll biosynthesis. Cadmium and chromium were reported to affect chlorophyll biosynthesis and inhibit protochlorophyll reductase and aminolevulinic acid (ALA) synthesis (Stobart et al., 1985). The inactivation of the enzymes involved in the chlorophyll biosynthetic pathway could also contribute to the general reduction in chlorophyll content. The present results showed that lead, copper and chromium toxicity decreased the chlorophyll a content of the two algae under investigation. The highest reduction in chlorophyll a content was found in algae exposed to chromium, followed by copper and lead. A large reduction in chlorophyll content due to $\mathrm{Cr}$ toxicity can be explained on the basis of destruction of stomata and mesophyll cells, which decreases their efficiency of light utilization and electron transport rates involving PS I and PS II (Munne-Bosch and Alegre, 2003; Hernandez et al., 2004).

In conclusion, in the present study, the bioaccumulation potential of two algal biomass Spirogyra communis and Chlorella pyrenoidosa have been assessed for the removal of $\mathrm{Pb}(\mathrm{II}), \mathrm{Cu}(\mathrm{II})$ and $\mathrm{Cr}$ (IV) from electroplating industrial effluent and aqueous solution. Experiments conducted on industrial effluent showed a significant decrease in physicochemical parameters and heavy metal content by both the algal biomass. The chlorophyll content of both algae was highly suppressed by high levels of $\mathrm{Cr}\left(>10 \mathrm{mg} \mathrm{L}^{-1}\right)$, while high concentration of $\mathrm{Pb}$ and $\mathrm{Cu}\left(>30 \mathrm{mg} \mathrm{L^{-1 }}\right)$ has less inhibitory effect and low concentrations (<50 $\mathrm{mg} \mathrm{L}^{-1}$ ) has stimulatory effects. $S$. communis and $C$. pyrenoidosa both are efficient biosorbents for heavy metal removal from industrial wastewaters containing low as well as high concentration of $\mathrm{Pb}, \mathrm{Cu}$ and $\mathrm{Cr}$. Their easy availability and cost effective nature make them most promising biosorbents over other conventional biosorbents. Bioaccumulation and biosorption of heavy metals utilizing $S$. communis and $C$. pyrenoidosa proved promising techniques to mitigate water pollution. The development of bioremediation processes using algal biomass requires further investigation

\section{Acknowledgement}

The laboratory facilities provided by G.B. Pant University of Agriculture and Technology, Pantnagar, India are gratefully acknowledged.

\section{References}

American Public Health Association (APHA) 1995. Standard Methods for the Examination for Water and Wastewater. $\left(19^{\text {th }}\right.$ edition). Byrd Prepess Springfield, Washington.

Bayo, J. 2012. Kinetic studies for Cd(II) biosorption from treated urban efluents by native grapefruit biomas (Citrus paradisi L.): The competive efect of $\mathrm{Pb}(\mathrm{II}), \mathrm{Cu}(\mathrm{II})$ and $\mathrm{Ni}(\mathrm{II})$. Chem. Engi. J., 191: 278-87.

Bulgariu, L., Bulgariu, D. 2014. Enhancing Biosorption Characteristics of Marine Green Algae (Ulva lactuca) for Heavy Metals Removal by Alkaline Treatment. Bioprocessing \& Biotechniques, 4: 1-6.

Crist, R.H., Oberholser, K., McGarrity, J., Crist, D.R., Johnson, J.K. \& Brittsan, J.M. 1992. Interaction of metals and protons with Marine algae, with emphasis on lead and aluminium. Environ. Sci. Technol., 26: 496-502.

Delfine, S., Alvino, A., Villiani, M.C. \& Loreta, F. 1999. Restrictions to carbon 
dioxide conductance and photosynthesis in spinach leaves recovering from salt stress. Plant Physiol., 119: 1101-1106.

Fernandez-Leborans, G. \& Novillo, A. 1996. Toxicity and bioaccumulation of cadmium in Olisthodiscus luteus (Raphidiophyceae). Water Res., 30: 57-62.

Foster, P.L. 1982. Metal resistances of Chlorophyta from rivers polluted by heavy metals. Freshwater Biol., 12: 41-61.

Gonzalez, B.Y., Rodriguez, R.I.L., Guibal, E., Calero de Hoces, M. \& MartinLara, M.A. 2012. Biosorption of hexavalent chromium from aqueous solution by Sargassum muticum brown alga. Application of statistical design for process optimization. Chemical Engi. J., 183: 68-76.

Hernandez, I., Alegre, 1. \& Munne-bosch, S. 2004. Drought-induced changes in flavonoids and other lowmolecularweight antioxidants in Cistus clusii plants grown under Mediterranean field conditions. Tree Physiol., 24: 1303-1311.

Monni, S., Uhlig, C., Junttila, O., Hansen, E. \& Hynynen, J. 2001. Chemical composition and ecophysiological responses of Empetrum nigrum to above ground element application. Environ. Pollu., 112: 417-426.

Munne-bosch, S. \& Alegre, 1. 2003. Drought-induced changes in the redox state of alpha-tocopherol, ascorbate, and the diterpene carnosic acid in chloroplasts of Labiatae species differing in carnosic acid contents. Plant Physiol., 131: 1816-1825.

Nassiri, Y., Wery, J., Mansot, J. \& Ginsburger-Vogel, T. 1997. Cadmium bioaccumulation in Tetraselmis suecica: an electron energy loss spectroscopy (EELS) study. Arch.
Environ. Contamination \& Toxicol., 33: 156-161.

Oyeku, O.T. \& Eludoyin, A.O. 2010. Heavy metal contamination of ground water resources in a Nigerian urban settlement. African J. Environ. Sci. Technol., 4(4): 201-214.

Pandey, J., Shubhashish, K. \& Pandey, R. 2010. Heavy metal contamination of Ganga river at Varanasi in relation to atmospheric deposition. J. Trop. Ecol., 51(2): 365-73.

Romera, E., Gonzalez, F., Ballester, A., Blazquez, M.L. \& Munoz, J.A. 2007. Comparative study of biosorption of heavy metals using different types of algae, Biores. Technol., 98: 33443353.

Siddiqui, W.A. \& Sharma, R.R. 2009. Assessment of the Impact of Industrial Effluents on Groundwater Quality in Okhala Industrial Area, New Delhi, India. E J. Chem., 6(1): 41-6.

Singh, A., Kumar, D., Gaur, J.P. 2012. Continuous metal removal from solution and industrial effluents using Spirogyra biomass-packed column reactor. Water Res., 46: 779-788.

Singh A, Saxena S, Gaur S \& Chauhan RK. 2006. Biological Effect of Heavy metal in drinking water of Shivalik \& western UP regions in India. Chem. Weekly, 5: 193-7.

Stobart, A.K., Griffiths, W.T., Ameenbukhari, I. \& Sherwood, R.P. 1985. The effect of $\mathrm{Cd}^{+2}$ on the biosynthesis of chlorophyll in leaves of barley. Physiologia Plantarum, 63: 293-298.

Stokes, P.M. 1983. Responses of freshwater algae to metals. Progress Phycol. Res., 2: 87-112.

Tuzen, M. \& Sary, A. 2010. Biosorption of selenium from aqueous solution by green algae (Cladophora hutchinsiae) biomass: Equilibrium, thermodynamic and kinetic studies. Chem. Engi. J,. 
158: 200-6.

Vonshak, A. 1997. Spirulina: Growth, physiology and biochemistry. In: Vonshak A, editor. Spirulina platensis (Arthrospira): Physiol. cell boil. Biotechnol., London: Taylor and Francis. pp 43-66.

Xia, Y. \& Liyuan, C. 2002. "Study of gelatinous Supports for Immobilizing
Inactivated Cells of Rhizopus oligosporus to Prepare Biosorbent for Lead Ions". Int. J. Environ. Studies, 5: 1-6.

Zou, H.X., Li, N., Wang, L.H., Yu, P. \& Yan, X.F. 2014. Equilibrium and Kinetic Studies of $\mathrm{Cd}^{2+}$ Biosorption by the Brown Algae Sargassum fusiforme. PLOS ONE, 9(4): 95-242.

\section{How to cite this article:}

Meenakshi Sati, Megha Verma and J.P.N. Rai. 2016. Phycoremediation of Heavy Metals by Chlorella pyrenoidosa and Spirogyra communis. Int.J.Curr.Microbiol.App.Sci. 5(10): 920-930. doi: http://dx.doi.org/10.20546/ijcmas.2016.510.099 